University of New Orleans

ScholarWorks@UNO

Philosophy Faculty Publications

Department of History and Philosophy

3-2007

\title{
Cultivating Virtue: Moral Progress and the Kantian State
}

Chris W. Surprenant

University of New Orleans, csurpren@uno.edu

Follow this and additional works at: https://scholarworks.uno.edu/phil_facpubs

Part of the Philosophy Commons

\section{Recommended Citation}

Surprenant, Chris W., "Cultivating Virtue: Moral Progress and the Kantian State," Kantian Review, Vol. 12, Issue 1 (2007): 90-112.

This Article is brought to you for free and open access by the Department of History and Philosophy at ScholarWorks@UNO. It has been accepted for inclusion in Philosophy Faculty Publications by an authorized administrator of ScholarWorks@UNO. For more information, please contact scholarworks@uno.edu. 


\section{Cultivating Virtue: Moral Progress and the Kantian State}

\author{
CHRIS W. SURPRENANT \\ Boston University
}

After examining the ethical and political writings of Immanuel Kant, one finds an apparent paradox in his philosophy as his perfectionist moral teachings appear to be linked to his antiperfectionist political theory. ${ }^{1}$ Specifically, he writes that the perfection of moral character can only take place for an individual who is inside of civil society, a condition where no laws may legitimately be implemented expressly for the purpose of trying to make individuals moral. Kant believes that living in civil society is a necessary condition for an individual to refine his talents and reason completely, a process required by morality. I believe, however, that the connection between his moral and political theory runs much deeper than simply facilitating the refinement of talents. Kant's moral theory focuses on an individual's cultivation of virtue, ${ }^{2}$ but this cultivation cannot be most satisfactorily completed unless that individual is a member of civil society. Put differently, civil society plays a necessary role in cultivating an individual's character so that he is able to act from maxims consistent with the moral law, out of the respect for the law itself. However, because he believes that civic laws primarily intended to encourage moral cultivation cannot be implemented legitimately, it seems curious that this condition should play such a significant role in Kant's moral philosophy. Through this examination of Kant's moral and political theory, it will be shown that Kant's political society establishes a condition necessary for an individual's complete cultivation of virtue, not by implementing laws that make men moral but by weakening the forces of heteronomy, thereby removing barriers to moral action.

In his writing, Kant distinguishes between the cultivation of virtue and simply willing in a manner consistent with right. A
CULTIVATING VIRTUE

virtuous individuatácts in accordance with maxims that are consistent with the moral law, out of duty to the law itself ( $G r 4$ : 393-402). Willing consistently with right, however, simply requires that one satisfy 'the formal condition of outer freedom' (MM 6: 380). This distinction separates actions that are morally praiseworthy from actions that are legally blameless. If an individual's action is consistent with external laws, then he and his action are consistent with legality, even if the motive behind this action was blameworthy. For example, an individual donates money to an orphanage for the sole purpose of telling others how generous he has been, thereby increasing his esteem in the community. While we would say that his action, the donation of money to individuals in need, was praiseworthy, we would also say that the motivation behind this action was not praiseworthy. This latter distinction is one of virtue, not right, and Kant examines the reasons behind one's actions to determine whether an individual is morally praiseworthy. Therefore, a virtuous individual is morally praiseworthy because he acts, and is always motivated to act, from moral maxims.

Reason is able to determine whether a particular maxim is consistent with morality by applying the categorical imperative. This imperative, 'act only in accordance with that maxim through which at the same time you can will that it become a universal law' ( $G r$ 4: 421), Kant writes, 'has to do not with the matter of the action and what is to result from it, but with the form and the principle for which the action itself follows; and the essentially good in the action consists in the disposition, let the result be what it may, (Gr 4: 416). The categorical imperative is the imperative of morality, and against it an individual is able to test maxims to determine whether or not they are consistent with the moral law. 'Any maxim that does not so qualify [as being consistent with the categorical imperative] is contrary to morals' (MM 6: 226). However, while an individual is able to make this determination, he can never be confident that he has identified the actual motivation behind one of his actions. ${ }^{3}$ Kant writes:

It is indeed sometimes the case that with the keenest self-examination we find nothing besides the moral ground of duty that could have been powerful enough to move us to this or that good action ... but from this it cannot be inferred with certainty that no covert impulse of selflove, under the mere pretense of that idea, was not actually the real 
determining cause of the will ... since, when moral worth is at issue, what counts is not actions, which one sees, but those inner principles that one does not see. $(G r 4: 407)$

A human being cannot see into the depths of his own heart so as to be quite certain, in even a single action, of the purity of his moral intention and the sincerity of his disposition, even when he has no doubt about the legality of the action. Very often he mistakes his own weakness, which counsels him against the venture of a misdeed, for virtue. (MM 6: 392)

An individual, therefore, is presented with a significant obstacle in the task of fully cultivating his own virtue: although reason has provided a test to determine whether a maxim is consistent with the moral law, an individual is unable to determine whether he has acted on this maxim out of respect for the moral law or due to heteronomous impulses. Without this knowledge, the task of fully cultivating virtue, a task required by morality, appears difficult at best.

In addition to this problem of being unable to identify with certainty what motivates our actions, cultivating virtue is a difficult task, for Kant appears to have an odd notion of what moral cultivation entails. The traditional view of moral cultivation is presented by Aristotle who believes that it is the culturing and development of appropriate tastes (NE 1106a15-1107a10, et al.). Contrary to Aristotle, Kant believes that moral cultivation involves the acquisition of apathy or indifference to one's passions, weakening one's tastes altogether as these tastes and desires serve to cause one to stray from the demands of morality. His understanding of apathy is not the same as our modern use of the word as a lack of feeling or indifference to a particular matter. Rather, Kant understands apathy, what he calls moral apathy, as not being affected by heteronomous impulses that cause one to act contrary to what the moral law demands. He writes:

Since virtue is based on inner freedom it contains a positive command to a human being, namely to bring all his capacities and inclinations under his (reason's) control and so to rule over himself, which goes beyond forbidding him to let himself be governed by his feelings and inclinations (the duty of apathy); for unless reason holds the reins of government in its own hands, his feelings and inclinations play the master over him. (MM 6: 408)

KANTIAN REVIEW, VOLUME 12, 2006
Kant's categorical imperative is used as a principle of reason to assist one in not only becoming apathetic to his own inclinations, but also in activelyoverning one's life in a manner consistent with morality. Cultivating virtue is not a passive activity, one that can be done by simply ignoring one's heteronomous inclinations. Rather, this cultivation requires one to actively master his own inclinations, using the categorical imperative as a means of making continual progress towards the complete alignment of his will with the moral law.

While the categorical imperative is useful in determining whether particular maxims are consistent with the moral law, it is difficult to apply because it is an abstract principle. However, in Kant's political philosophy, this principle is brought closer to our intuition through the presentation of two additional principles: the universal principle of right and the supreme principle of the doctrine of virtue. The universal principle of right is used to determine whether an action is consistent with right, and it states: 'Any action is right if it can coexist with everyone's freedom in accordance with a universal law, or if on its maxim the freedom of choice of each can coexist with everyone's freedom in accordance with a universal law' (MM 6:230). The supreme principle of the doctrine of virtue is used to determine whether an action is consistent with virtue, and it states: 'Act in accordance with a maxim of ends that it can be a universal law for everyone to have' (MM: 6: 395). These principles allow us to determine whether an individual is morally praiseworthy. One is morally praiseworthy when he acts from a subjective principle consistent with universal freedom (i.e. acting in accordance with right) and, at the same time, when he is motivated to act in accordance with this maxim by the objective, universal law (i.e. acting in accordance with virtue). Additionally, these principles allow us to understand how the establishment of a moral condition (i.e. a cosmopolitan community) is possible through the establishment of a rightful condition occupied by virtuous individuals (i.e. civil society). Kant believes that the moral law demands that individuals not only act in accordance with right, but also act from moral motives that consider all individuals, including the actor, as ends and not simply as means. He writes, 'That [one] make it [his] maxim to act rightly is a demand that ethics makes... and it is not enough that he is not authorized to use either himself or others merely as means (since he could then still be indifferent to

KANTLAN REVIEW, VOLUME 12, 2006 
them); it is in itself his duty to make the human being as such his end' (MM 6:231, 6:395).

Since the project here is to show that the progress towards the complete cultivation of virtue requires being a part of a rightful condition, a connection among right, morality, and progress towards the complete cultivation of virtue must be shown to exist in Kant's philosophy. To arrive at this connection, we will proceed by examining Kant's moral theory, paying particular attention to the role of virtue, its cultivation, and the relationship between it and the categorical imperative. From there, it will be shown that Kant believes living in civil society is a necessary, but insufficient, condition for one to be able to fulfill his moral duties. The role of civil society, however, goes beyond simply acting as a condition in which morality can be attained. Ultimately, I will show that an individual can hope to fully cultivate virtue only if he is a member of civil society, for this condition both removes barriers to moral action and conditions an individual in such a way that he cultivates virtue through the reformation of his moral motivation.

The claim that Kant's moral theory focuses on virtue and an individual's cultivation of his own virtuous character is fairly uncontroversial. In the much cited opening to the Groundwork, Kant tells us that the good will is the only thing that can be considered good without limitation, and that it 'seems to constitute the indispensable condition even of worthiness to be happy' ( $\mathrm{Gr}$ 4: 393). Further, he writes that individuals have been given reason in order to allow them to better satisfy their needs and desires, but that 'the true vocation of reason must be to produce a will that is good, not perhaps as a means to other purposes, but good in itself' (Gr 4: 396). Kant's moral theory in the remainder of the Groundwork, as well as the subsequent investigation in the second Critique, is dedicated to outlining morality from the perspective of the individual. In this way, his theory is different from other moral theories that attempt to provide an individual with guidelines for determining whether or not others have acted morally. Kant believes that one can never determine whether others have acted from moral motivations, so he outlines the method by which an individual, through his reason, is able to arrive at moral judgements about his own actions. Otfried Höfe agrees with this assessment of Kant's moral theory as presented in the Groundwork and second Critique, noting that these works address the personal side of morality, or how individuals are able to attain absolute goodness (1994: 142).

To attain absolute goodness, the complete cultivation of virtue, one must act in accord with what morality demands. This requirement, however, is not specific enough, for Kant believes that in determining morality it is the maxims of actions that are import ant, not the results of these actions. He writes:

The moral worth of an action does not lie in the effect expected from it and so too does not lie in any principle of action that needs to borrow its motive from this expected effect... Nothing other than the representation of the law in itself, which can of course occur only in a rational being, insofar as it and not the hoped for effect is the determining ground of the will, can constitute the preeminent good we call moral, which is already present in the person himself who acts in accordance with this representation and need not wait upon the effect of his action ... When moral worth is at issue, what counts is not actions, which one sees, but those inner principles of actions that one does not see. (Gr 4: 401, 4: 408)

These inner principles are often the motivation behind an individual's actions. In the case of morally praiseworthy actions, these inner principles consist of the recognition and respect for the moral law. Therefore, Kant's criterion for morality, as Höffe notes, 'is met only if one does what is morally correct for no other reason than because it is morally correct. An action is good without qualification only if it fulfills duty for the sake of duty' (1994: 143).

In addition to simply formulating the categorical imperative, for Kant's moral philosophy to succeed he must also show that this imperative is real and that individuals are motivated by it - otherwise, morality remains simply a 'chimerical idea without any truth' ( Gr 4: 445). Christine Korsgaard adds that if the moral law does not affect the wills of individuals, then morality would simply be 'a dogma of rationalist metaphysics which does not apply to the world' (1996: 24). As she correctly perceives, Kant needs a transition from this metaphysics of morals to his critique of practical reason, showing how a law of pure reason is able to apply to the will. This transition centres on the idea of the will, but here Kant is not speaking specifically about what he has called the good will; rather, he addresses an individual's free will. A free will is one that achieves both the negative and positive conception of freedom: not only is it not determined by any external influences (i.e. it possesses

KANTIAN REVIEW, VOLUME 12, 2006 
negative freedom), but it also determines its own actions for particular reasons (i.e. it possesses positive freedom) ( $G r$ 4: 448). In other words, a free will is a will that is determined by its own law or principle, and this principle, for all wills, is the moral law - 'a free will and a will under moral laws are one and the same' (Gr 4: 447). Unlike external laws that could determine a will, making it not free in the negative sense, the moral law has no content, but has only the form of law. Therefore, as Korsgaard notes, 'the moral law simply describes the position of a free will. When the will's choices are directed by the moral law, it expresses its spontaneity. The moral law is the law of spontaneity. The will that is governed by morality is free' (1996: 25).

Human beings, however, are not entirely free as they are often turned away from morality by desire, for 'it is not the case that everyone willingly obeys [morality's] precept when it is in conflict with his inclinations' (CPrR 5:37). This quality separates individuals and their character, that which has the potential to become good, from the nature of the divine, that which is holy. Three types of properties are important to this examination. The first is divine nature, a property possessed by beings that are not capable of acting on a maxim that conflicts with the moral law (CPrR 5:32). The second is virtue, a property possessed by beings that, while tempted by desire to act in a manner contrary to morals, always act on maxims that are consistent with the moral law. The third is lack of virtue, or uncultivated virtue, a property possessed by beings who, while having the potential to always act in accordance with the moral law, give in to desire and act according to heteronomous impulses. ${ }^{4}$ The primary focus here is on divine nature and virtue, as the difference between these two properties can be understood when examining how each arrives at its maxims. Kant writes, 'The fitness of the maxims of every good will to make themselves into universal law is the sole law that the will of every rational being imposes upon itself, without having to put underneath it some incentive or interest as a basis' $(G r 4: 444)$. In order for an individual to progress from a stage where he is moved by heteronomous impulses (i.e. non-virtuous) to one where he has apathy towards these impulses (i.e. virtuous), a progression that is required by the moral law, moral cultivation is required. Put differently, humans are under a moral obligation to train themselves to act in a manner that is consistent with the moral law, grounded in
CULTIVATING VIRTUE

respect for the law itself. Unlike divine beings which act in accordance with the moral law by nature, never being tempted to act otherwise, an indixidual's desires tempt him to act contrary to the moral law. In this way, for an individual to acquire virtue he must not give in to his desires, often thereby neglecting what he wishes to do and compromising his happiness.

While it is not easy to act in ways that force us to set aside our own happiness for the sake of morality, Kant believes that it is not impossible. As he observes, "to satisfy the categorical command of morality is within everyone's power at all times; to satisfy the empirically conditioned precept of happiness is but seldom possible' ( $C \operatorname{Pr} R 5: 37)$. Fully satisfying the categorical imperative, however, is not a task that one is able to complete alone. As Allen Wood notes, Kantian ethics is grounded on the dignity of rational nature. It requires not only respect for individual rights and the equal worth of human beings, but also the idea of a cosmopolitan community in which the ends of all rational beings must form a unity to be pursued collectively' (1999: 2). The creation of this cosmopolitan community is seen as being necessary for the full realization of Kant's ethical philosophy, and the origin of this community is found in the creation of civil society. Described as a condition of distributive justice ( $M M$ 6: 307), civil society is the rightful condition individuals enter into after leaving the state of nature, the non-rightful original condition that lacks distributive justice. Entering into civil society is the first step towards the realization of a cosmopolitan community, and Kant tells us that individuals have a moral obligation to take this step. '[Individuals] do wrong in the highest degree by willing to be and to remain in a condition that is not rightful, that is, in which no one is assured of what is his against violence' (MM 6: 308-9). Kant even goes so far as to say that coercing another to enter into civil society, when he resists entering on his own volition, is consistent with right and virtue and, therefore, consistent with the moral law (TP 8: 292-3; MM 6:306).

At the very least, the claim that coercion is justified in order to compel an individual into entering civil society, thereby facilitating the progression towards a cosmopolitan community, shows that there exists some relationship between Kant's understanding of virtue and the establishment of civil society. In his essay on Universal History, we are given more insight into the nature of this relationship. Kant writes:

KANTIAN REVIEW, VOLUME 12,2006 
The greatest problem for the human species, whose solution nature compels it to seek, is to achieve a universal civil society administered in accord with right ... since it is only in such a society that nature's highest objective, namely, the highest attainable development of mankind's capacities, can be achieved, nature also wills that mankind should itself accomplish this, as well as all the other goals that constitute mankind's vocation. (UH $8: 22$ )

An individual's development of his capacities, specifically his moral and natural personalities, is not something that is seen as merely being beneficial for his existence in civil society. Rather, Kant believes that an individual has a duty to develop these capacities. There are two types of duties that an individual has to himself, negative and positive, and examining both provides us with further clues as to the relationship between ethics and civil society. Kant notes:

[Negative duties] belong to the moral health of a human being as object of both his outer senses and inner sense, to the preservation of his nature in its perfection. [Positive duties] belong to his moral prosperity, which consists in possessing a capacity sufficient for all of his ends, insofar as this can be acquired; they belong to his cultivation (active perfecting) of himself. - The first principle of duty to oneself lies in the dictum 'live in conformity with nature', that is, preserve yourself in the perfection of your nature; the second, in the saying 'make yourself more perfect than mere nature has made you'. (MM 6:419)

While an individual can preserve himself and live in conformity with nature outside of civil society, it is possible for him to fulfill his positive duties (i.e. making himself more perfect than nature has made him) only when inside a civil society administered in accordance with right.

Why, however, must an individual be inside civil society to develop fully and perfect his natural capacities? Kant's argument is that human reason, the capacity which is being fully developed when one is a member of civil society, 'does not operate on instinct, but requires trial, practice and instruction in order gradually to progress from one stage to another' (UH 8: 19). Obtaining this type of training is not only dependent on the immediate assistance of one's fellow community members, but also on the evolution of reason that is passed down from generation to generation. Put differently, in order for one to fulfill his moral duty to develop his own reason to the highest prossible degree, that individual must, at the very least, be a member of civil society. ${ }^{5}$ Kant adds:

[In civil society] all man's talents are gradually developed, his taste is cultured, and through progressive enlightenment he begins to establish a way of thinking that can in time transform the crude natural capacity for moral discrimination into definite practical principles and thus transform a pathologically enforced agreement into a society and, finally, into a moral whole. (UH 8: 21)

After examining these passages, it can be seen that one's positive duties to himself provide one connection between the cultivation of virtue and Kant's moral theory. One's moral obligations to himself, stemming from these specific positive duties, can only be satisfactorily fulfilled by an individual who is a member of a rightful social condition.

An individual's positive duties, however, go beyond simply perfecting his natural abilities, for they require that he make himself more perfect than nature has made him. This statement, however, appears quite curious, for it seems difficult to imagine how one would be able to perfect his capacities beyond their natural limitations. Kant has already provided us with a solution to this apparent problem: the cultivation of virtue. Unlike the nature of divine beings, individuals are not naturally inclined to always act in accordance with the moral law. Human beings, because they are not beings of pure reason, often choose to act in ways that bring them pleasure, rather than in ways that are consistent with morality. Human virtue, therefore, is understood as an individual's choosing the moral law over pleasure, autonomy over heteronomy, thereby using his rationality to overcome his natural state. In the words of Jeffrie Murphy, 'Kant's point is that human actions are moral (because rational) only in so far as they do not find their justification in appeal to sensuous inclination or desire. And this is because it is only by acting in this way ... that man reveals his dignity - asserts that autonomy which distinguishes him from the brutes' (1994: 30). Therefore, cultivating virtue is seen as a positive duty that an individual has to himself, for completing this cultivation would be to make himself more perfect than nature has made him.

The role of civil society goes far beyond simply providing an environment in which an individual is able to perfect his natural

KANTIAN REVIEW, VOLUME 12,2006 
talents, for civil society is seen by Kant as being necessary for the complete cultivation of virtue. ${ }^{6}$ This point is made directly in Perpetual Peace. He writes:

Within each state [a malevolence rooted in human nature] is veiled by the coercion of civil laws, for the citizens' inclination to violence against one another is powerfully counteracted by a greater force, namely that of the government, and so not only does this give the whole a moral veneer but also, by its checking the outbreak of unlawful inclinations, the development of the moral predisposition to immediate respect for right is actually greatly facilitated. (PP 8:375n-376 n., emphasis added.)

From this passage, it is clear that there exists some connection between the cultivation of virtue, the thrust of Kant's moral theory, and the formation of civil society, the starting point for Kant's political theory. Allen Rosen agrees with this assessment of the connection between Kant's ethical and political thought. He notes, 'Kant believes that political society is a training ground for inner morality ... the state makes it easier for the "capacities of human beings to develop into an immediate respect for right", and even though this is not yet a "moral step", it is nonetheless a definite step toward morality' (1993: 77). Put differently, while Kant believes that civil society cannot make men moral, it is a condition necessary for the full moral development of any individual.

There are two components of this position. The first is that morality requires a type of training in order for it to be fully cultivated inside an individual, and the second is that this type of training can only be done satisfactorily while inside civil society. On the subject of moral training, this issue appears to be at odds with two of Kant's positions. First, moral habituation is inconsistent with his ethical philosophy because an individual acting from habit loses a degree of freedom simply because this action is done from habit and not from duty (MM 6: 409). Moral training, however, is not the same thing as moral habituation. The process of moral training involves an individual acquiring knowledge, and the ability to process this knowledge is necessary for moral decision making. This process, however, appears to conflict with Kant's well-established position that knowledge of what the moral law requires is obtained a priori (CPR A807/B835, et al.), for necessary moral training suggests that additional knowledge is needed in order to make moral decisions. Specifically, if we are able to know before experience, what the moral law requires of us, how is training, the process of learning from action and experience, supposed to helpin cultivating virtue?

A misconception is that Kant's understanding of 'a priori', when discussing the moral law, is that what we have knowledge of a priori can be known without being derived from elements in the sensible world. Examining our test of maxims to determine whether or not they are consistent with the moral law disproves this understanding of Kant's use of 'a priori'. A maxim is consistent with the moral law if it can be universalized, and to determine whether a particular maxim passes this test we must consider what the adjusted social order, a term introduced by John Rawls, would look like if the maxim were, in fact, universalized. In Rawls's words, 'we are to adjoin the as-if law of nature ... to the existing laws of nature (as these are understood by us) and then think through as best we can what the order of nature would be once the effects of the newly adjoined law of nature have had sufficient time to work themselves out' $(2000: 169)$. To think through what the order of nature would be after we universalized a particular maxim, we must have knowledge of the existing natural order. However, we do not need knowledge of what the natural order would be after we have decided to universalize the maxim in question (i.e. a posteriori knowledge). Kant believes that we can use our reason to determine the moral standing of this future condition, thereby determining the morality of a particular maxim before we act on it.

Human reason is able to determine the morality of maxims because the moral law comes from within each individual, instead of imposing itself on individual human wills ( $M M$ 6: 216). Although the course of history and development of reason have allowed individuals to purify their understanding of what this law demands (CPR A817/B845), it is the human will that generates the moral law. Therefore, it is the human will, not God, which generates the standard by which actions are determined to be moral or immoral. Frederick Beiser adds:

The political implications of Kant's new ethics are therefore radical in the extreme. If the human will creates moral values, so that it is obliged to obey only the laws of its own making, then it has the right to recreate the entire social and political world. The onus is now on society and the state, not on the individual. Rather than individuals conforming to a

KANTIAN REVIEW, VOLUME 12, 2006 101 
divinely sanctioned social and political order, it must conform to the demands of their will. (1992: 31)

The point here is not that it is the state's responsibility to legislate morality, but rather that civil society and its institutions are responsible for the continued purification of one's understanding of the moral law, as well as ensuring a condition that allows for each individual's cultivation of virtue.

There are two ways that civil society could assist an individual in this process, either by taking direct action that compels individuals to act in accordance with the moral law, or through indirect action that seeks to remove barriers that prevent individuals from acting morally. Acting in accordance with the moral law is a duty of virtue, and duties of virtue cannot be the subject of external lawgiving. Therefore, 'no external lawgiving can bring about someone's setting an end for himself (because this is an internal act of the mind), although it may prescribe external actions that lead to an end without the subject making it his end' (MM 6: 239). In this way, legislators and state authorities are prohibited from passing laws that have the intent of making men moral, primarily because such legislative actions are misguided and beyond the function of those authorities. However, in a rather puzzling passage from part 2 of the Metaphysics of Morals, Kant writes that the function of the state authorities is to provide for 'security, convenience and decency; for, the government's business of guiding the people by laws is made easier when the feeling of decency, as negative taste, is not deadened by what offends the moral sense' (MM 6: 325). The problem arises when trying to reconcile this passage with Kant's anti-perfectionist political philosophy, and then further reconciling it with his notion of moral cultivation that involves an individual weakening the strength of his heteronomous impulses.

One solution is that civil society and the state can assist an individual's cultivation of virtue by removing barriers to morality. As we have seen, one such barrier is undeveloped reason, and civil society helps to remove this barrier by facilitating the development and use of reason. Additionally, civil society and the state are able to take more active measures to assist an individual's moral progress. As Alexander Kaufman notes:

Clearly, Kant does require that right regulates merely external acts and not the choice of ends. Yet there is a meaningful distinction between

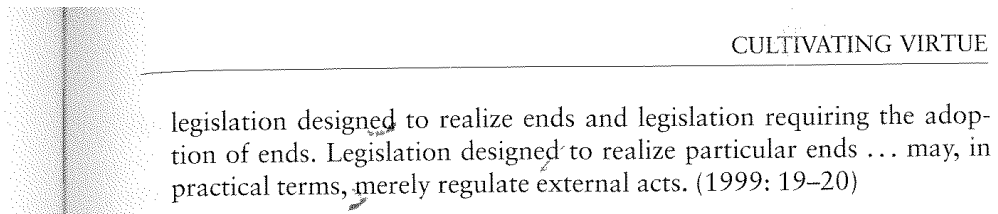

While Kant believes the state should not go so far as to enact laws that aim primarily at the moral cultivation of its citizens, laws can be used to assist the state in guiding its citizens and removing potential barriers to morality. If a law is passed with the intent of providing for the security, convenience, or decency of the citizens, and, by chance, it also assists in the moral development of the citizens, Kant believes it is legitimate. As with his moral theory, the intent of the law is what matters most in determining its legitimacy. State legislators do no wrong if laws produce the effect, albeit not primarily intended, of guiding a nation's citizens towards the cultivation of their own virtue and the establishment of a rightful condition.

In addition to simply establishing these laws, it is also necessary that citizens obey the laws to maintain this condition. Obedience to civic laws is a moral obligation, for living inside civil society, and, thus, maintaining civil society, is necessary for one's own moral cultivation. However, obedience to the law is not an inherent property of individuals, but a quality that must be adopted and cultivated. What encourages this cultivation is not only that the state imposes penalties on individuals who violate the law (fines, imprisonment, etc.), but also that citizens recognize the connection between the obedience to laws and maintaining civil society. Through citizens habituating their duty to obey civic laws, Kant believes they begin the acquisition of virtue. The virtue acquired is not civic virtue, but the robust, moral form of virtue that he addresses in his moral theory (Rel 6:47).

Although it is now clear that Kant believes civil society plays a fundamental role in an individual's cultivation of virtue, a question remains as to how this process occurs. While many philosophers before Kant also believed that the state played a fundamental role in cultivating morality, a sufficient explanation for how this process occurs had yet to be formulated. For example, let us consider the theories of Aristotle and Jean-Jacques Rousseau. Aristotle writes:

Legislators should urge people towards virtue and exhort them to aim at what is fine... Someone who is to be good must be finely brought up 
and habituated, and then must live in decent practices, doing nothing base either willingly or unwillingly. And this will be true if his life follows some sort of understanding and correct order that has influence over him. (NE 1180a5-15)

The state, therefore, plays a necessary role in an individual's progression from incontinence to continence to, ultimately, virtue. An individual's progression from stage to stage is due to civic law, for it 'has the power that compels; and law is the reason that proceeds from a sort of intelligence and understanding' (NE $1180 a 20-5)$. While this explanation may provide an account of how one moves from incontinence to continence, it does not explain how one acquires virtue - the highest stage at which he is not enticed by base pleasures.

Rousseau's explanation for how this process occurs is unsatisfactory as well. Much like Aristotle, he believes that the state plays a role in moral development. He writes:

The mere appearance of order brings [a citizen] to know order and to love it. The public good, which serves others only as a pretext, is a real motive for him alone. He learns to struggle with himself, to conquer himself, to sacrifice his interest to the common interest. It is not true that he draws no profit from the laws. They give bim the courage to be just even among wicked men. It is not true that they have not made him free. They have taught him to reign over himself. (Em 473, emphasis added)

Unlike Aristotle, Rousseau provides us with a better account of how this process occurs. By protecting the rights of individuals, the state instills a feeling within a citizen that he will be protected from individuals who may try to take advantage of his virtuous character. However, as both we and Rousseau recognize, even in a state that provides for the protection of rights and upholds order, individuals still act contrary to moral law. Ultimately, for Rousseau, an individual can become completely virtuous only by looking inside himself and acting in accord with what reason and his conscious dictate. He concludes, '[The external laws of nature] are written in the depth of [the wise man's] heart by conscious and reason. It is to these that he ought to enslave himself in order to be free ... Freedom is found in no form of government; it is in the heart of the free man' ( $E m$ 473). Unlike Aristotle who believes that learning and habituation to laws will cause one to become virtuous,
Rousseau believes that one will either acquire or not acquire virtue - the decision is up to the individual: Rousseau, however, provides no explanation for how, exactly, this process occurs.

Unlike Aristotle and Rousseau, Kant provides an explanation to answer this question of how one is able to cultivate virtue. This explanation, however, does not directly involve civil society. He writes:

A human being's moral education must begin not with an improvement of mores, but with the transformation of his attitude of mind and the establishment of a character... This predisposition to the good is cultivated in no better way than by just adducing the example of good people (as regards their conformity to law), and by allowing our apprentices in morality to judge the impurity of certain maxims on the basis of the incentives actually behind their actions. And so the predisposition gradually becomes an attitude of mind, so that duty merely for itself begins to acquire in the apprentice's heart a noticeable importance. (Rel 6: 48)

Kant believes that civil society provides the tools necessary for this cultivation to occur: knowledge of existing conditions, intellectual development, etc. ${ }^{7}$ It is the individual himself, however, who must complete this revolution of mores by becoming apathetic to heteronomous impulses and open to the moral law. This process is neither completed alone, nor with the direct assistance of civil society. Rather, an individual's complete cultivation of virtue occurs in a series of steps, all of which are dependent upon that individual being a member of civil society and, ultimately, being open to divine assistance.

While not often considered to be part of his political theory, Kant's writings in his Religion essay provide us with insight on this connection among civil society, religion, and an individual's acquisition of virtue. He writes:

When the firm resolve to comply with one's duty has become a habit, it is called virtue in the legal sense, in its empirical character. Virtue here has the abiding maxim of lawful actions, no matter whence one draws the incentives that the power of choice needs for such actions. Virtue, in this sense, is accordingly acquired little by little, and to some it means a long habituation (in the observance of the law), in virtue of which a human being, through gradual reformation of conduct and consolidation of his maxims, passes from a propensity to vice to its opposite. (Rel $6: 47)$

KANTIAN REVIEW, VOLUME 12, 2006 
and habituated, and then must live in decent practices, doing nothing base either willingly or unwillingly. And this will be true if his life follows some sort of understanding and correct order that has influence over him. (NE 1180a5-15)

The state, therefore, plays a necessary role in an individual's progression from incontinence to continence to, ultimately, virtue. An individual's progression from stage to stage is due to civic law, for it 'has the power that compels; and law is the reason that proceeds from a sort of intelligence and understanding' (NE 1180a20-5). While this explanation may provide an account of how one moves from incontinence to continence, it does not explain how one acquires virtue - the highest stage at which he is not enticed by base pleasures.

Rousseau's explanation for how this process occurs is unsatisfactory as well. Much like Aristotle, he believes that the state plays a role in moral development. He writes:

The mere appearance of order brings [a citizen] to know order and to love it. The public good, which serves others only as a pretext, is a real motive for him alone. He learns to struggle with himself, to conquer himself, to sacrifice his interest to the common interest. It is not true that he draws no profit from the laws. They give him the courage to be just even among wicked men. It is not true that they have not made him free. They have taught him to reign over himself. ( $E m 473$, emphasis added)

Unlike Aristotle, Rousseau provides us with a better account of how this process occurs. By protecting the rights of individuals, the state instills a feeling within a citizen that he will be protected from individuals who may try to take advantage of his virtuous character. However, as both we and Rousseau recognize, even in a state that provides for the protection of rights and upholds order, individuals still act contrary to moral law. Ultimately, for Rousseau, an individual can become completely virtuous only by looking inside himself and acting in accord with what reason and his conscious dictate. He concludes, '[The external laws of nature] are written in the depth of [the wise man's] heart by conscious and reason. It is to these that he ought to enslave himself in order to be free... Freedom is found in no form of government; it is in the heart of the free man' (Em 473). Unlike Aristotle who believes that learning and habituation to laws will cause one to become virtuous,
Rousseau believes that onewill either acquire or not acquire virtue - the decision is up to the individual. Rousseau, however, provides no explanation for how, exactly, this process occurs.

Unlike Aristotle and Rousseau, Kant provides an explanation to answer this question of how one is able to cultivate virtue. This explanation, however, does not directly involve civil society. He writes:

A human being's mofal education must begin not with an improvement of mores, but with the transformation of his attitude of mind and the establishment of a character... This predisposition to the good is cultivated in no better way than by just adducing the example of good people (as regards their conformity to law), and by allowing our apprentices in morality to judge the impurity of certain maxims on the basis of the incentives actually behind their actions. And so the predisposition gradually becomes an attitude of mind, so that duty merely for itself begins to acquire in the apprentice's heart a noticeable importance. (Rel 6: 48)

Kant believes that civil society provides the tools necessary for this cultivation to occur: knowledge of existing conditions, intellectual development, etc. ${ }^{7}$ It is the individual himself, however, who must complete this revolution of mores by becoming apathetic to heteronomous impulses and open to the moral law. This process is neither completed alone, nor with the direct assistance of civil society. Rather, an individual's complete cultivation of virtue occurs in a series of steps, all of which are dependent upon that individual being a member of civil society and, ultimately, being open to divine assistance.

While not often considered to be part of his political theory, Kant's writings in his Religion essay provide us with insight on this connection among civil society, religion, and an individual's acquisition of virtue. He writes:

When the firm resolve to comply with one's duty has become a habit, it is called virtue in the legal sense, in its empirical character. Virtue here has the abiding maxim of lawful actions, no matter whence one draws the incentives that the power of choice needs for such actions. Virtue, in this sense, is accordingly acquired little by little, and to some it means a long habituation (in the observance of the law), in virtue of which a human being, through gradual reformation of conduct and consolidation of his maxims, passes from a propensity to vice to its opposite. (Rel $6: 47)$ 
The process of acquiring virtue in this manner can only occur for those inside civil society, for the state of nature is a condition, by definition, that lacks the laws and condition of community necessary for this gradual reformation of conduct to take place. While cultivating civic virtue is a step in the direction of cultivating moral virtue, it is important to recognize that these two types of virtue are not seen by Kant as being equal. Put differently, it would be incorrect to believe that one who has conditioned himself to always act in accordance with civic laws has fully cultivated virtue.

To further this point, Kant states directly that the simple fact of one living in civil society is not sufficient for one to improve himself. He notes:

Some supernatural cooperation is also needed to his becoming good or better, whether this cooperation only consist in the diminution of obstacles or be also a positive assistance, the human being must nonetheless make himself antecedently worthy of receiving it; and he must accept this help (which is no small matter), i.e., he must incorporate this positive increase of force into his maxim: in this way alone is it possible that good be imputed to him, and that he be acknowledged a good human being. (Rel 6:44)

Arguably, the very act of joining into civil society would allow an individual to begin the process of making himself worthy to receive divine assistance. Practically speaking, however, few individuals actively decide to enter into civil society. Even when Kant describes the formation of civil society out of the state of nature, it is unclear how many individuals chose to join, and how many were compelled to join through morally justified coercion. Rather, individuals are conditioned into recognizing the state of civil society that they were born into, and the first steps in an individual's moral education is this conditioning process. These initial steps, however, simply teach an individual to act in accordance with legality, instilling within him that he should act in certain ways, not out of a respect for the law but out of a fear of punishment. Kant continues:

That a human being should become not merely legally good, but morally good (pleasing to God) i.e. virtuous according to the intelligible character [of virtue] and thus in need of no other incentive to recognize a duty except the representation of duty itself - that, so long as the foundation of the maxims of the human being remains impure, cannot be effected through gradual reform but must rather be effected through a revolution in the disposition of the human being (a transition to the maxim of holiness of disposition). And so a "new man' can come about only through a kind of yebirth, as it were a new creation ... and a change of heart. (Rel 6: 47)

-

His argument is that even though an individual is conditioned to perform actions that are in accordance with the law, this conditioning affects the maxim behind an individual's action, not the motivation which led him to adopt this maxim. For one to take steps towards the complete cultivation of virtue, the conditioning must affect what motivates an individual to act - the objective principle of volition.

Altering the motivation behind why an individual adopts a particular maxim is understood by Kant to be a significant change, for it affects the disposition of the individual. This change is revolutionary because it transforms an individual's outlook concerning the world around him. Instead of selfish motivations that produce actions that may or may not be consistent with the legality of civic laws, the individual now acts out of respect for the law itself. In other words, he now acts out of respect for his fellow citizens as rational beings deserving of dignity. How is this revolution possible given that conditioning encouraged by civil society and by one's fellow citizens appears to only affect the maxims one adopts, and not the motivation behind how they are adopted? Kant responds:

The only way to reconcile this is by saying that a revolution is necessary in the mode of thought but a gradual reformation in the mode of sense (which places obstacles in the way of the former), and [that both] must therefore be possible also to the human being. That is: If by a single and unalterable decision a human being reverses the supreme ground of his maxims by which he was an evil human being (and thereby puts on a 'new man'), he is to this extent, by principle and attitude of mind, a subject receptive to the good; but he is a good human being only in incessant laboring and becoming i.e. he can hope ... to find himself upon the good (though narrow) path of constant progress from bad to better. (Rel 6:47-8)

Not only does Kant believe that an individual is able to reform his actions so that they are consistent with civic laws, but he also believes that through gradual reformation an individual is able to change his personality so as to develop this moral motivation. 'For the judgment of human beings... who can assess themselves and

KANTIAN REVIEW, VOLUME 12, 2006 107 
the strength of their maxims only by the upper hand they gain over the sense in time, the change is to be regarded only as an evercontinuing striving for the better, hence as a gradual reformation of the propensity to evil, of the perverted attitude of mind' (Rel 6:48).

In order for an individual to satisfy the positive moral duties he has to himself, thereby making himself more perfect than nature has made him, he must exist in a condition conducive to his own moral development. Like other skills that an individual possesses, acting in accordance with moral maxims from moral motivations is a skill that requires practice, perfection, and, ultimately, divine assistance in order to complete. Moral training is necessary, and this training begins when an individual enters into civil society. While, at first, an individual follows the rules of civil society not out of respect for the law itself but due to some heteronomous motivation (fear of punishment, desire for esteem, etc.), Kant believes that divine assistance will assist an individual in conforming his will to the moral law out of respect for the law itself, as well as out of respect for others in society. Ultimately, it is only through civil society that an individual is able to cultivate virtue completely, as this condition allows him to exercise fully his autonomy and exhibit it to others whom he recognizes, and who recognize him, as rational beings capable of moral decision making.

\section{Notes}

$\because$ I owe great thanks to Joseph Reisert and Cheshire Calhoun for their many helpful suggestions and time spent reading drafts of this paper. With that said, any errors in this work remain entirely my own responsibility.

1 Perfectionism, as it is usually defined, is a doctrine that focuses on the completion of an individual's moral character as its ultimate goal. When applied to political philosophy, a state is perfectionist when the legislative aim is the promotion of morals and values. It is this understanding of perfectionism that is often applied to Kant's theory. While the focus of Kant's moral theory is the perfection of an individual's moral character (i.e. the cultivation of the good will), he also believes that the state cannot pass legislation that primarily aims at this purpose. There is also a softer version of perfectionism in political philosophy in which the state or civil society is seen as significantly contributing to the betterment of an individual's moral character. I will argue that Kant supports this softer version of perfectionism in his political writings.

2 Often when one talks about the cultivation of virtue for Kant, the word virtue is substituted for the term good will. Strictly speaking, however, a good will is not something that can be cultivated. When Kant speaks of the good will, what he is referring to are the principles that an individual adopts, not the condition of the individual adopting them, for Kant recognizes that an individual can adopt good maxims (i.e. possessa good will) but lack the virtue to act on those maxims. He writes, 'weakness in the use of one's understanding coupled with the strength of one's emotions is only a lack of virtue and, as it were, something childish and weak, which can indeed coexist with the best will' (MM 6: 408). While an individual cannot cultivate a good will, he is able to cultivate a good temperament (i.e. the sentimental condition that may influence the maxims upon which he acts), a good character (i.e. the disposition to freely act from good principles) and, ultimately, virtue (i.e. the strength of character to act from maxims in conformity with the moral law out of duty to the law itself, even when acting in this manner is contrary to one's inclination towards happiness). I am in debt to an anonymous reviewer for these observations.

3 It is important to clarify the difference between maxim and motivation in Kant's moral theory. A maxim is defined as the subjective principle for acting, and this principle is to be distinguished from the objective principle for acting, what Kant identifies as the practical law. The maxim behind an action 'contains the practical rule determined by reason conformably with the conditions of the subject (often his ignorance or also his inclinations), and is therefore the principle in accordance with which the subject acts; but the law is the objective principle valid for every rational being, and the principle in accordance with which he ought to act' $(G r$ 4: 421n.). For example, suppose an individual acts from the following maxim: I will not lie in order to remove myself from difficulty. Different individuals, however, may be motivated to act in accordance with this maxim for different reasons - one may not lie out of recognition that the moral law forbids it, another may not lie out of fear of being found out and the repercussions that would go along with being labelled as a liar. Therefore, just because two individuals are acting from the same maxim, what motivates them to act in this way may not be the same. Further, because Kant's moral system is set up from the perspective of the individual, an individual is not concerned with the motivations of others, but simply what motivates his own actions. Specifically, an individual is concerned with whether he is motivated to act from maxims consistent with the moral law out of respect for the law itself, and not motivated by heteronomous impulses.

KANTIAN REVIEW, VOLUME 12, 2006 
4 It is helpful to compare these three properties to Aristotle's understanding of virtue, continence, incontinence and vice. On virtue and vice, Aristotle writes, "Virtue, then, is (a) state that decides, (b) [consisting] in a mean, (c) the mean relative to us, (d) which is defined by reference to reason, (e) i.e., to the reason by reference to which the intelligent person would define it. It is a mean between two vices, one of excess and one of deficiency' (NE 1106b40-1107a5). Continence and incontinence, while falling between vice and virtue, are a 'different kind' of state (NE 1145b1-2). On these two characteristics, Aristotle notes, "The continent person seems to be the same as one who abides by his rational calculation; and the incontinent person seems to be the same as the one who abandons it. The incontinent person knows that his actions are base, but does them because of his feelings, while the continent person knows that his appetites are base, but because of reason does not follow them' (NE 1145b10-15). While the continent person is closer to acquiring virtue than the incontinent because he is able to refrain from giving in to these base appetites, part of him still desires to take part in these lower pleasures. The completely virtuous individual, however, is not moved by these appetites. Kant's discussion of these three properties (sometimes identified in the text as the holy will, fully cultivated good will and human will) follows a similar progression. A being with uncultivated virtue, like the incontinent man, is moved by and gives in to base appetites-heteronomous impulses in the sensible world. As an individual refrains more and more from acting on these impulses, he is able to cultivate virtue. Like the continent man, a virtuous individual often desires to act on these impulses but refrains from doing so, thereby always acting in accord. ance with the moral law. Divine nature, which Kant tells is that individuals must make eternal progress towards, is one that is never affected by these impulses, similar to Aristotle's virtuous man.

5 It should be noted that being a member of civil society is a necessary but not sufficient condition for one to fulfill these negative duties, for he would still have to act in ways conducive to developing his natural capacities as a member of civil society.

6 G. Felicitas Munzel advances a similar thesis. 'In regard to the question of how to understand the relation of the exercise of such external agency (whether by nature's hand or political order) to moral cultivation', he writes, 'as a negative task, discipline eliminates the obstacles to cultivation, both in terms of the expenditures of resources and the effectuation of a "state of peace in which laws have force". Moreover, the formal moral order is not only maintained intact, but indeed through this [republican] constitution, the formal principle of universal justice is concretely embodied in the historical, human community' (1999: 322). For more on Kant's pedagogical views concerning civil society and moral education, see Kant's Conception of Moral Character (especially chapters 4/and 5).

Kant does mention thatyan individual living outside of the state of nature is able to act in accordance with maxims that are consistent with the moral law. Horwever, because this individual does not have the benefit of others and the historical development of reason that has produced a refinement of the moral law, it impossible for him to cultivate his good will to the fullest extent. Once inside civil society, an individual is able to begin his moral education that has the potential of leading to the fullest possible cultivation of his own good will.

\section{References}

Aristotle. (1985). Nicomachean Ethics, transl. Terence Irwin (Indianapolis: Hackett).

Beiser, Frederick. (1992). Enlightenment, Revolution, and Romanticism: The Genesis of Modern German Political Thought, 1790-1800 (Cambridge: Harvard University Press).

Höffe, Otfried. (1994). Immanuel Kant (Albany: State University of New York Press).

Kant, Immanuel. (1998). Critique of Pure Reason (CPR), transl. Paul Guyer and Allen Wood, in The Cambridge Edition of the Works of Immanuel Kant: Critique of Pure Reason (Cambridge: Cambridge University Press).

Kant, Immanuel. (1983). 'Idea for a universal history with a cosmopolitan intent' (UH). transl. Ted Humphrey, in Immanuel Kant: Perpetual Peace and Other Essays (Indianapolis: Hackett Publishing Company).

Kant, Immanuel. (1996). 'Religion within the boundaries of mere reason' (Rel), transl. George di Giovanni, in The Cambridge Edition of the Works of Immanuel Kant: Religion and Rational Theology (Cambridge: Cambridge University Press).

Kant, Immanuel. (1999). 'Groundwork of the Metaphysics of Morals' (GR), transl. Mary Gregor in The Cambridge Edition of the Works of Immanuel Kant: Practical Philosophy (Cambridge: Cambridge University Press).

Kant, Immanuel. (1999). 'Critique of Practical Reason' (CPrR), transl. Mary Gregor, in The Cambridge Edition of the Works of Immanuel Kant: Practical Philosophy (Cambridge: Cambridge University Press).

Kant, Immanuel. (1999). 'On the common saying: that may be correct in theory, but it is of no use in practice' (TP), transl. Mary Gregor, in The Cambridge Edition of the Works of Immanuel Kant: Practical Philosophy (Cambridge: Cambridge University Press).

KANTIAN REVIEW, VOLUME 12, 2006 
Kant, Immanuel. (1999). 'Toward perpetual peace' (PP), transl. Mary Gregor, in The Cambridge Edition of the Works of Immanuel Kant: Practical Philosophy (Cambridge: Cambridge University Press).

Kant, Immanuel. (1999). 'The Metaphysics of Morals' (MM), transl. Mary Gregor, in The Cambridge Edition of the Works of Immanuel Kant: Practical Philosophy (Cambridge: Cambridge University Press).

Kaufman, Alexander. (1999). Welfare in the Kantian State (Oxford: Oxford University Press).

Korsgaard, Christine. (1996). Creating the Kingdom of Ends (New York: Cambridge University Press).

Munzel, G. Felicitas. (1999). Kant's Conception of Moral Character (Chicago: University of Chicago Press).

Murphy, Jeffrie G. (1994). Kant: The Philosophy of Right (Macon: Mercer University Press).

Rawls, John. (2000). Lectures on the History of Moral Philosophy (Cambridge: Harvard University Press).

Rosen, Allen D. (1993). Kant's Theory of Justice (Ithaca: Cornell University Press).

Rousseau, Jean-Jacques. (1979). Emile: Or, On Education (EM), transl. Allan Bloom (New York: Basic Books).

Wood, Allen. (1999). Kant's Ethical Thought (Cambridge: Cambridge University Press). 